Ger J Exerc Sport Res

https://doi.org/10.1007/s12662-021-00786-8

Received: 5 March 2021

Accepted: 10 November 2021

(c) The Author(s) 2021

\section{Sven Schneider ${ }^{1}$ (D) $\cdot$ Hans-Guido Mücke ${ }^{2}$}

'Mannheim Institute of Public Health, Social and Preventive Medicine, Medical Faculty Mannheim, Heidelberg University, Mannheim, Germany

${ }^{2}$ German Environment Agency/Umweltbundesamt, Berlin, Germany

\title{
Sport and climate change-how will climate change affect sport?
}

\section{Climate change as a blind spot in sports science}

Climate change represents what is probably the greatest challenge to face humanity this century. It has complex consequences for the environment, society, economy and people's health (Eichinger, 2019; Townsend et al., 2003). It is therefore all the more surprising that the issue of climate change has received comparatively little attention to date in the fields of sports science. However, it will not only be professional athletes, but also amateurs, spectators and officials who are directly confronted with the adverse implications of climate change on our health in the near future. Moreover, in addition to elderly people, patients requiring long-term care and young children, athletes are explicitly considered to be a risk group with regard to climate change-related health risks (Hanna, Kjellstrom, Bennett, \& Dear, 2011; Mücke \& Matzarakis, 2019; World Health Organisation, 2019).

Both professional and recreational sport will therefore need to respond to these developments. With regard to sports science, this represents both a challenge and an opportunity at the same time. Recently, Abu Omar and Gelius explained in this journal how sport can (and should) contribute to mitigate climate change ("climate change mitigation"; Abu-Omar \& Gelius, 2020). We would like to follow this up and continue the discussion by presenting how sport can (and should) adapt to climate change ("climate change adaptation").

\section{Sport-specific risks caused by climate change}

Sport-specific risks caused by climate change are differentiated between direct and indirect health-related effects (Eis, Helm, Laußmann, \& Stark, 2010; Mücke \& Matzarakis, 2019). Direct consequences are primarily caused by extreme temperature and other weather conditions (e.g. heatwaves, extreme weather events, ultraviolet (UV) radiation), while indirect consequences are a result of climate-induced changes to our ecosystem (e.g. air pollutants, allergens, viruses and bacteria as well as the associated vectors and natural reservoirs) (Mücke \& Matzarakis, 2019). • Figure 1 presents a brief summary of the environment and health challenges that have been discussed in academic literature to date.

\section{Heatwaves}

Climate change is predominantly described in the media as an increase in annual mean global temperatures. In the last 100 years, the mean annual temperature in Germany, for example, has risen by approximately $1^{\circ} \mathrm{C}$. Here, a further increase of $1-3^{\circ} \mathrm{C}$ is predicted by the middle of the century and a $2-4^{\circ} \mathrm{C}$ increase by the end of the century (Eis et al., 2010; Stamatakis, Nnoaham, Foster, \& Scarborough, 2013). However, this indicator only depicts one aspect of the thermal changes that are happening. For athletes, it is much more relevant in this context tolook at the foreseeable increase, scope and duration of short to medium periods of extreme air temperatures in the summer ("heatwaves"), which have already been observed over the last two decades (Mücke \& Litvinovitch, 2020). There is still no internationally agreed definition of the term "heatwave". However, it is predicted that the number of hot days with temperatures over $30^{\circ} \mathrm{C}$ will triple in Germany by the end of this century and that valleys and basins are particularly threatened by this change (Algesheimer, 2019; Eis et al., 2010).

Impact on health: In general, increased outdoor temperatures cause increased stress on the cardiovascular, respiratory and metabolic systems (Mücke \& Matzarakis, 2019). People who exercise in hot conditions are thus exposed to heat stress which can jeopardize their health (Brotherhood, 2008; Kappas, 2009; Townsend et al., 2003). Hot environmental conditions result from the mean skin temperature, the mean radiant temperature, the air temperature, the air velocity over the body, the saturated vapour pressure at skin temperature, and the ambient vapour pressure (Brotherhood, 2008; Mücke \& Matzarakis, 2019). Heat stress not only affects outdoor sports (e.g. football, rugby, hockey, athletics, tennis), but also those who exercise indoors if they have to train in insufficiently air-conditioned, overheated sports halls and gyms. The human body acclimatizes to this type of thermophysiological stress by increasing plasma volume and sweat rate and starting to produce sweat earlier (Maloney \& Forbes, 2011). However, such an acclimatization process takes longer than the (currently typical) duration of most local heatwaves. It is recommended to adjust gradually by regularly exposing the body to stress over a period of at 


\section{Discussion}

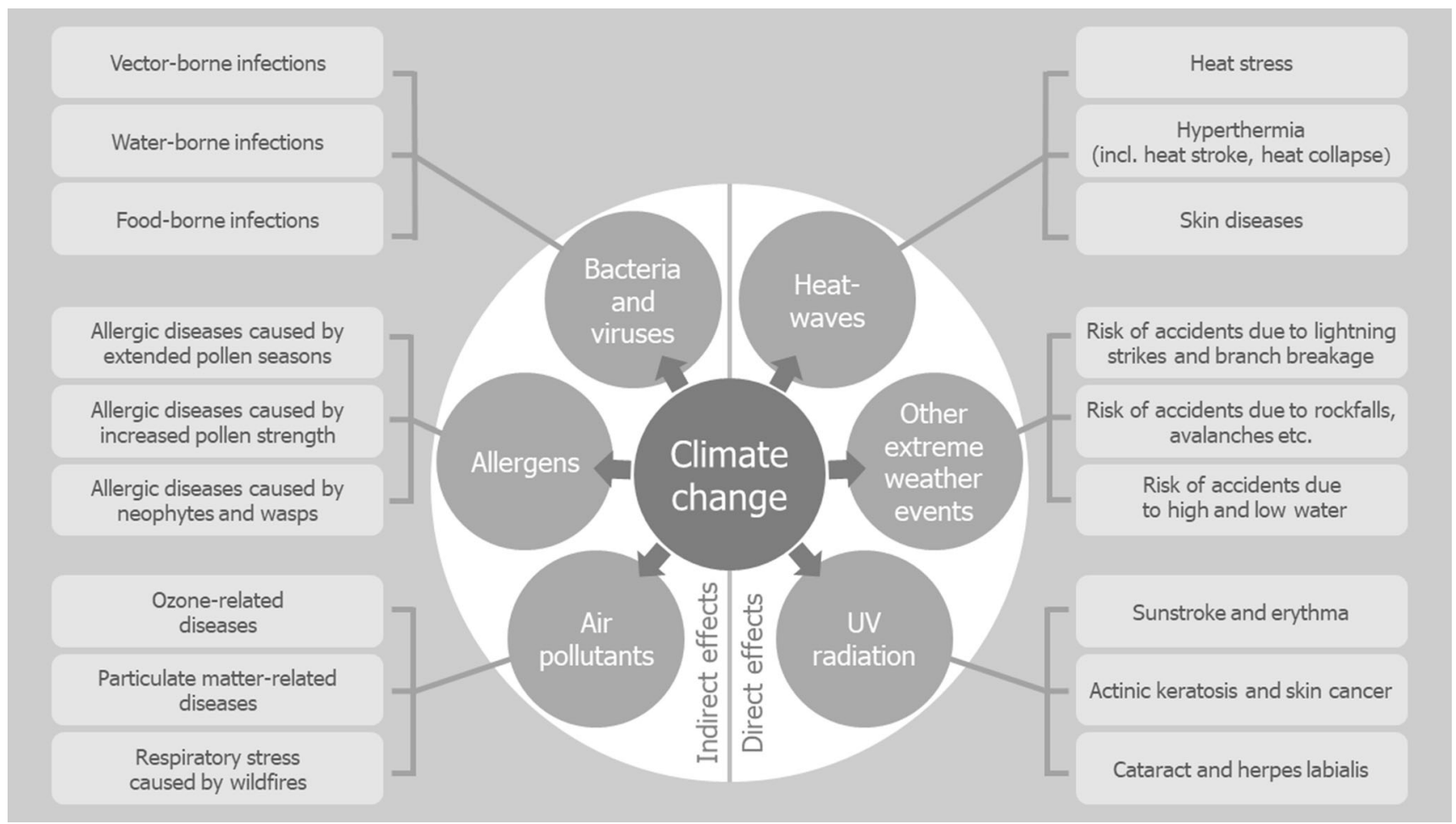

Fig. $1 \Delta$ Direct and indirect sport-specific risks caused by climate change

least two weeks (Eis et al., 2010; Wonisch \& Ledl-Kurkowski, 2017). The decisive factor in this context is the body core temperature because a core temperature exceeding about $41.5^{\circ} \mathrm{C}$ usually endangers thermal regulation. Even if body core temperature is not directly dependent upon ambient temperature, thermoregulation is compromised when exposed to great physical stress combined with high outdoor temperature and air humidity (Brotherhood, 2008; Hanna et al., 2011). High levels of air humidity impede perspiration, thus causing heat to remain in the body and increasing core body temperature (Maloney \& Forbes, 2011). Well-trained athletes have an individual tolerance to increases in core body temperature that is about $0.9^{\circ} \mathrm{C}$ higher than that of untrained individuals (Hanna et al., 2011). But without an intact thermal regulation, the body can lose its ability to regulate temperature which can then lead to an acute emergency situation (Eis et al., 2010; Wonisch \& Ledl-Kurkowski, 2017). Hyperthermia typically leads to heat stroke, collapse, heat exhaustion and heat cramps (Brotherhood, 2008; Mücke \& Matzarakis, 2019).
Compared with heat stroke-which can be a life-threatening event-and the risks previously mentioned, other effects of heat that have been discussed in literature seem somewhat marginal (heat rashes, i.e. miliaria and yeast infections, e.g. pityriasis versicolor; Karamfilov \& Elsner, 2002).

Prevention: In the event of prolonged thermal stress, the following preventive measures are recommended: conducting sports activities during morning or evening hours; adjusting scope of training; regular intake of fluid before, during and after activity; wearing breathable clothing; taking a break from all sporting activities in the event of gastrointestinal or febrile illness; avoiding alcohol and medication that affect the body's electrolyte balance (diuretics, anticholinergics, neuroleptics) (Wonisch \& Ledl-Kurkowski, 2017; World Health Organisation, 2019).

\section{Other extreme weather events}

In addition to the heat waves already mentioned, the acceleration of the water cycle is another consequence of climate change. In Germany, annual precipita- tion has increased by about $11 \%$ since the meteorological measurements had been started in 1881. Increasing precipitation, however, exclusively affected the winter half-years. In contrast, the summer months have tended to become drier. Extreme weather events such as lightning strikes, storms, broken tree branches, heavy rainfall and flooding will increase due to climate change (Eis et al., 2010).

Impact on health: Of all the climate impacts shown in $\bullet$ Fig. 1, the impact of extreme weather events on sport is the least considered in the relevant literature to date (Neuerburg \& Quardokus, 2019; Orr \& Inoue, 2019). Extreme weather events pose hazards from lightning strikes and drought-related branch breakage to many outdoor sports (e.g. golf, football, hiking, jogging). In addition, increased temperatures pose a fundamental risk to skiers and mountaineers (melting glaciers and permafrost areas, landslides, rockfalls, crevasses and avalanches) and water sports enthusiasts (dangerous changes to water current speeds) (Algesheimer, 2019).

Prevention: In Germany, the Federal Office for Civil Protection and Disaster Assistance provides information about 
dangerous weather conditions, e.g. via the NINA warning app (Bundesamt für Bevölkerungsschutz und Katastrophenhilfe, Bonn, Germany).

\section{UV radiation}

There are at least three reasons why climate change could increase ultraviolet exposure for athletes. Firstly, the emission of certain greenhouse gases leads to the depletion of the ozone layer in the stratosphere ("ozone holes"), thus causing an increase in low-lying UVB radiation (Townsend et al., 2003). As a result, UV radiation at higher altitudes has increased by up to $25 \%$ in spring and $10 \%$ in summer over the last 30 years. This increase appears to be slightly less extreme in low-lying regions, due to cloud cover and air pollutants (Jendritzky, 2007). Stratospheric low ozone events ("mini ozone holes"), which occur in the temperate latitudes of the northern hemisphere, particularly in the spring, are especially dangerous. These short-term phenomena have also been recorded in Germany and can, e.g. for those partaking in winter sports, be particularly stressful to the skin, which is not yet adapted to such high levels of UV radiation, especially during the winter (Baldermann \& Lorenz, 2019). Secondly, the number of sunny days is increasing due to climate change. In the last 50 years, average sunshine duration in Germany has increased by around $100 \mathrm{~h}$ per year (Baldermann \& Lorenz, 2019). Thirdly, milder winter conditions and a longer outdoor season lead to an overall increase in the amount of time that athletes spend outside, thereby also increasing their annual amount of UV exposure (Mücke \& Matzarakis, 2019).

Impact on health: In particular, acute effects of excessive, unprotected UV exposure include sunstroke, i.e. aseptic meningitis (inflammation of the meninges) or swelling of the brain tissue (cerebral edema) and UV erythema (sunburn) (Mücke \& Matzarakis, 2019). Long-term UV exposure over many years is typical in many different sports (e.g. triathlon, rowing, golf, sailing), which can lead to chronic implications such as actinic keratosis, malignant melanomas and non-melanocytic skin cancer (basal cell carcinoma, squamous cell carcinoma) (Algesheimer, 2019; Diehl, Schneider, \& Görig, 2019). Nonmelanocytic skin cancers in particular are caused by the long-term effects of UV radiation. Long-term cumulative UV radiation is associated with a higher risk of developing squamous cell carcinoma, while the main risk factors for developing basal cell carcinoma are frequent occurrence of sunburn and high levels of intermittent UV exposure. The latter is also a risk factor for the development of malignant melanomas (Diehl et al., 2019).

In addition to this, increased or more frequent exposure to UV radiation also accelerates photoaging in the skin. This is not only affected by the amount of exposure to the sun, but also by skin pigmentation; athletes with fair skin are thus particularly at risk (Diehl et al., 2019).

The additional UV exposure caused by reflection from the snow can cause people partaking in winter sports (e.g. alpine skiing, biathlon) to develop recurrent herpes labialis. UV radiation is a potent stimulus and frequently causes the reactivation of latent herpes simplex virus infections (Karamfilov \& Elsner, 2002). Excess sunlight exposure not only has a diverse range of dermatological implications, it also has a number of ophthalmological effects as well. Athletes such as rowers and winter sports enthusiasts who expose themselves to high levels of UV radiation without any form of protection are at risk of developing diseases in the periorbital region, conjunctiva (pterygium), cornea (keratoconjunctivitis), lens (cataracts) and retina (photic retinopathy) (Eis et al., 2010; Mücke \& Matzarakis, 2017; Schneider, Görig, Schilling, Schuster, \& Diehl, 2019).

Prevention: Preventive measures can be split into behavioural prevention measures (e.g. wearing sunglasses, sun protection, lip balm with UV protection, wearing long-sleeved clothing and head coverings as well as-wherever possible-not exercising in the middle of the day and keeping to shady areas) and structural prevention measures (e.g. increasing access to shady areas, use of floor
Ger J Exerc Sport Res

https://doi.org/10.1007/s12662-021-00786-8

(c) The Author(s) 2021

\section{S. Schneider · H.-G. Mücke \\ Sport and climate change-how will climate change affect sport?}

\section{Abstract}

Climate change will have complex consequences for the environment, society, economy and people's health. The issue of climate change has received comparatively little attention to date in the fields of sports science. Thus, sport-related health risks caused by climate change are discussed and summarized in a conceptual model presented here for the first time. Climate change is associated with the following increases of health-related risks for athletes in particular: Direct consequences caused by extreme temperature and other extreme weather events (e.g. increasing risks due to heatwaves, thunderstorms, floods, lightning, ultraviolet radiation) and indirect consequences as a result of climate-induced changes to our ecosystem (e.g. due to increased air pollution by ozone, higher exposures to allergens, increasing risks of infection by viruses and bacteria and the associated vectors and reservoir organisms). Each aspect is supplemented with advice on the prevention of health hazards. Not only individual athletes but also sports organizations and local clubs will have to respond to the changes in our climate, so that they can appropriately protect both athletes and spectators and ensure a plannable continuation of the sport in the future.

\section{Keywords}

Environment - Prevention - Physical activity . Risk · Prevention

surfaces with low albedo levels) (Schneider et al., 2019).

\section{Air pollutants}

After the presentation of the direct risks caused by climate change, the description of the indirect risks now follows: Ground-level ozone is an indicator of secondary photochemical pollutants, which are formed from nitrogen oxides and hydrocarbons-which are primarily emitted by motor traffic-when exposed to UV radiation (Schweisfurth, 
1994; Umweltbundesamt, 2016). Adverse effects from ground-level ozone mainly occur in the summer months (Eis et al., 2010; Mücke \& Matzarakis, 2019). Global warming is expected to lead to an increase in stable high pressure weather conditions and associated average temperatures as well as periods of extreme heat. Climate models therefore predict an increase in levels of ozone pollution in Germany (Brasseur, Jacob, \& SchuckZöller, 2017).

Air pollution caused by anthropogenic particulate matter has fallen significantly in Germany over the last few decades. On the one hand, technical developments can be expected to lead to further reductions in overall emissions. On the other hand however, climate change also induces specific weather conditions (heatwaves and droughts) which can lead to a significant increase in particulate matter pollution (Brasseur et al., 2017; Eis et al., 2010). Furthermore, the combination of heat, ozone and particulate matter results in strong synergistic interactions. Climate change also causes long dry periods and wildfires, which further contribute to the increase in natural particulate matter in the air (Eis et al., 2010; Hanna et al., 2011; Mathias, 2018).

Impact on health: Ozone sensitivity is subject to large fluctuations between individuals. Ozone causes inflammation in the alveoli and makes the body more prone to infection. It also promotes inflammatory reactions in the respiratory tract and-especially during physical exertion-can lead to deterioration in lung function, irritation of the mucous membrane, coughing, tiredness and reduced performance levels (Mathias, 2018; Mücke \& Matzarakis, 2019). It is possible to adapt to higher ozone levels; this usually occurs within four days and returns to original levels about a week after exposure has stopped. However, this change should be seen as a loss of defence mechanisms rather than true adaptation. Athletes are classed as a risk group as their overall ozone intake increases as their breathing rate increases (Schweisfurth, 1994; Wonisch \& Ledl-Kurkowski, 2017). The same is true for exposure to particulate matter (Eis et al., 2010). Particles smaller than
$2.5 \mu \mathrm{m}$ are especially harmful as these can penetrate the alveoli and lead to a diffusion of pro-inflammatory signalling molecules, atherosclerotic processes and chronic changes to the respiratory tract (Mathias, 2018). Particulate matter from large-scale wildfires can likewise have an impact on our health (Brasseur et al., 2017).

Prevention: In Germany, there is a requirement to issue a warning when the one-hour ozone value rises above $180 \mu \mathrm{g} / \mathrm{m}^{3}$. The German Environment Agency recommends carefully assessing the need to participate in open-air sports events if the one-hour ozone value rises above $120 \mu \mathrm{g} / \mathrm{m}^{3}$. Guidelines in individual federal states differ in terms of the type of events covered and the recommended measures (Umweltbundesamt, 2016). In general, sports activities should not be scheduled to take place in the summer between $11 \mathrm{am}$ and $6 \mathrm{pm}$ as ozone concentration is particularly high during this time (Mathias, 2018).

\section{Allergens}

As a result of climate change and the resulting milder weather conditions, seasonal pollen calendars are beginning to start earlier and end later than before. The last 20 years have already seen pollen seasons lengthening by between 6 and 19 days depending on plant species. According to model calculations for Germany, we can expect to see pollen seasons starting a further 20 days earlier by the end of the century (Eis et al., 2010).

In addition to the length of the pollen season, climate change also affects the concentration and allergenic potential of pollen (Katelaris \& Beggs, 2018). Whether the increased concentrations of atmospheric $\mathrm{CO}_{2}$ and the sustained rise in mean temperatures will have a positive long-term effect on biomass production in the form of a "fertilization effect" has yet to be conclusively determined (Beggs \& Bambrick, 2005; Höflich, 2014). However, it has been proven that there is an association between average annual and monthly temperatures and the concentration of birch pollen, olive pollen and other types of tree pollen (Höflich, 2014). In addition to higher concentrations of pollen, changes have also been observed in the allergenic potential of pollen (Stöver, 2015). The composition of protein in plant pollens is changed by pollutants such as fine particulate matter and ozone, which can make pollen more aggressive (Stöver, 2015).

Impact on health: Climate-induced changes in the quantity and quality of exposure to allergenic pollens are likely to lead to more frequent and more severe sensitization processes in the future (Eis et al., 2010). As exposure is not only restricted to the time spent exercising, this effect of climate change affects both outdoor and indoor athletes to varying degrees. The allergy-related effects of climate change described here have been found to be partly responsible for the rapidly increasing prevalence of asthma that has been observed in industrial countries for decades (Beggs \& Bambrick, 2005).

The changes to our climate detected in recent decades are also favourable for the naturalization and spread of neophytes with allergenic potential. In addition to giant hogweed and goldenrod, common ragweed (ambrosia artemisiifolia) is also relevant in this context (Mücke \& Matzarakis, 2019). Here in Germany, approximately $8 \%$ of all adults are already sensitized to ragweed (Eis et al., 2010). Within Europe, Germany expects to see one of the sharpest increases in sensitization to ragweed (Lake et al., 2017). For a quarter of all pollen allergy sufferers, allergic symptoms include asthma as well as allergic rhinitis (pollinosis). Animal allergen producers such as the oak processionary moth can also trigger asthma in some cases. In favourable weather conditions, broken urticating bristles are carried by air currents, thus also presenting an additional risk for endurance athletes and other outdoor sports enthusiasts (Eis et al., 2010).

Wasps also like warm conditions. It is still unclear how their food spectrum, predators and parasites will change as a result of climate change. Milder winter conditions may mean that not only the queens live through the winter, but the whole colony too, which could then go on to build very big nests in the spring 
(von Orlow, 2020). In general, it is assumed that a weather-induced increase in outdoor activities could also lead to more frequent encounters between athletes with an allergy to insect venom and individual animals or nests (Eis et al., 2010).

Prevention: In addition to following established drug treatments (antihistamines, allergen-specific immunotherapy), the German Association for Sports Medicine and Prevention (Deutsche Gesellschaft für Sportmedizin und Prävention [DGSP]) recommends that pollen allergy sufferers engage in classic forms of endurance sport such as running, swimming, cycling or hiking, provided that their current physical condition allows for this. When exercising outdoors, athletes should take care to warm up and cool down appropriately, avoid peak efforts and abrupt changes between resting and high effort. They should also stop exercising immediately in the event of an allergic reaction, an asthma attack or if they experience difficulty breathing. Medication should be taken following consultation with a doctor, taking relevant doping regulations into consideration (Deutsche Gesellschaft für Sportmedizin und Prävention, 2017). Concerning medication, it should also be noted that antihistamines and anticholinergics inhibit sweat secretion, which can affect heat balance. One way to avoid wasp stings is to stay away from any nests that may be found around playing fields, diving pools or storage rooms. Another method is to use insect repellent containing the active ingredient ethyl butylacetylaminopropionate.

\section{Bacteria and viruses}

Discussions are ongoing as to whether climate change is causing a greater increase in the reproduction and spread of vectors and natural reservoirs (Eis et al., 2010; Mücke \& Matzarakis, 2017; Ogden \& Lindsay, 2016; Townsend et al., 2003). A vector is a living organism that carries and transmits an infectious pathogen from one infected animal or person to another. The majority of vectors are ectotherms for whom global warming generally entails improved living conditions (Eis et al., 2010). Natural reservoirs are host animals that allow pathogens to gather and multiply, and from which a new infection can spread. Ticks are particularly relevant in this context (Jendritzky, 2007). Mild winters produce favourable conditions for a high density and greater activity of native tick species (castor bean tick or Ixodes ricinus and meadow tick or Dermacentor reticulatus) in the spring. However, very hot and dry summers cause a reduction in the population such that the regional impact of climate change has yet to be conclusively ascertained (Hemmer, Emmerich, Loebermann, Frimmel, \& Reisinger, 2018; Jendritzky, 2007; Mücke \& Matzarakis, 2017). Early findings of a new tropical tick species-Hyalomma marginatum-have been reported in recent years. A hot, dry climate poses no problem at all for this species (Hemmer et al., 2018). According to model calculations, the crucial parameter affecting the spread of ticks is the number of frost-free days (Eis et al., 2010). In general, climate change also creates more favorable conditions for the proliferation and survival of numerous other vectors such as the Anopheles mosquito, the sand fly (Phlebotiminae) and the Asian tiger mosquito (Aedes albopictus). Furthermore, milder winters and a more abundant food supply (including beechnuts) also correlates with higher survival rates for natural reservoirs such as striped field mice, shrews, common voles and bank voles (Eis et al., 2010; Faulde, Fock, Hoffmann, \& Pietsch, 2002; Reil et al., 2018; Stark, Niedrig, Biederbick, Merkert, \& Hacker, 2009).

Climate change compromises the quality of water used for bathing or water sports and encourages favourable conditions for water-borne infections. For canoeists and other water sports enthusiasts, cyanobacteria-also commonly known as blue-green algae-are most relevant in this context. An excess supply of nutrients can lead to the massive growth of cyanobacteria, creating algal blooms. This phenomenon is facilitated by a stable thermal stratification of a body of water, which is primarily caused by high temperatures and stable weather conditions. An increase in this type of blue-green algal bloom in upper layers of lake water is to be expected as a result of climate change (Eis et al., 2010; Mücke \& Matzarakis, 2017; Umweltbundesamt, 2019). Vibrio vulnificus is a species of a group of bacteria of the genus Vibrio, which occur naturally in brackish water and seawater. Coastal shore waters that are low in salt and subject to freshwater influx, such as river estuaries, are considered particularly vulnerable (Baker-Austin et al., 2013). The concentration of these bacteria can increase significantly when water temperatures rise above $20^{\circ} \mathrm{C}$, which happens for extended periods at the Baltic and North Seas in particular as a result of climate change (Eis et al., 2010; Mücke \& Matzarakis, 2017). Finally, the risks of food-borne infections also need to be considered.

Impact on health: Ticks in Germany have been found to carry at least ten viruses that are harmful to humans including Q fever, Rickettsia and Ehrlichia (Jendritzky, 2007; Kappas, 2009). Germany is also considered to be a highly endemic region for Lyme disease, the most common tick-borne disease, in particular (Mücke \& Matzarakis, 2017). In total, up to $5 \%$ of all local animals are infected with the virus. In Germany's highly endemic areas, almost 1 in 10 tick bites leads to a borreliosis infection. Unlike tick-borne encephalitis, there is currently no vaccine for Lyme disease (Eis et al., 2010). Athletes who exercise outdoors (e.g. team sports, athletics) and especially those exercising in fields and forests (e.g. jogging, Nordic walking, horse riding, hiking) form a specific risk group for contracting tick-related infections (Karamfilov \& Elsner, 2002).

Furthermore, milder winters mean that both mosquito species native to Germany and those encroaching from the Mediterranean can develop vector capabilities for diseases that have not previously played a significant role in Germany. At the same time, climate change also affects the flight paths of migratory birds that act as natural reservoirs. Both Asian tiger mosquitoes (Aedes albopictus) and sand flies (Phlebotiminae), which transmit Leishmania parasites, have been found in the Rhine 
Rift Valley (Jendritzky, 2007). Experts in tropical diseases expect to see outbreaks-small-scale ones initially-of dengue fever, Zika virus, West Nile fever and malaria in Germany. It is highly likely that chikungunya fever will become established in Germany (Hemmer et al., 2018).

In general, the incidence of hantavirus infections, which are transmitted by reservoirs such as striped field mice and bank voles, varies greatly from year to year. In the state of Baden-Wuerttemberg for example, serological tests have shown that up to $30 \%$ of all rodents have a prevalence of hantavirus antibodies (Jendritzky, 2007). However, as transmission primarily occurs via the respiratory system and only rarely through bites or other direct contact with animals, the risk for outdoor athletes remains relatively limited. One exception is hikers in endemic areas who use forest cabins that are inhabited by mice (Eis et al., 2010).

Due to their ability to produce a range of different toxins, cyanobacteria pose a danger to water sports enthusiasts (e.g. canoeists, rowers, windsurfers, water skiers). Swallowing water polluted with cyanotoxins manifests with acute gastrointestinal discomfort whilst skin contact with the film of bacteria can cause allergic reactions and skin irritation. Vibrio bacteria can cause diarrhoea, wound infections and septicaemia. In Germany, isolated cases of severe illness have been reported among elderly swimmers with pre-existing health conditions in the Baltic Sea (Eis et al., 2010).

It has been proven that there is a link between outdoor temperature and foodrelated infections caused by Salmonella, Campylobacter jejuni and Campylobacter coli. Studies and model calculations predict that an average increase of annual mean temperatures by $1{ }^{\circ} \mathrm{C}$ could lead to a $5-15 \%$ increase in the incidence of bacterial gastroenteritis (Eis et al., 2010).

Prevention: Athletes can follow current guidelines on how to prevent tick bites. These recommend that you should wear close-fitting clothing, avoid walking through undergrowth, thoroughly check the entire body for ticks, and remove them quickly (Deutsche Gesellschaft für Dermatologie, 2016; Kaiser, Archelos-Garcia, Jilg, Rauer, \& Sturzenegger, 2017). Insect repellents are also available that repel both ticks and mosquitoes. With regard to the recommendations published by the Robert Koch Institute regarding the prevention of hantavirus infections, the most relevant suggestion for hikers and outdoor athletes is to ensure that all water, food and waste is sealed in airtight containers and not accessible to rodents (Robert Koch-Institut, 2019). The German Canoe Association (Deutscher Kanu-Verband [DKV]) recommends that canoeists refrain from practicing rolling techniques when canoeing on waters polluted with bluegreen algal blooms. Care should also be taken to ensure adequate hand hygiene during breaks and after paddling, especially prior to handling food. In order to prevent water-borne infections, open wounds should be well covered with an appropriate dressing or contact with water should be avoided altogether (Deutscher Kanu-Verband, 2020; Robert Koch-Institut, 2006). Food-related infections at sports events where food is provided can be avoided by ensuring a seamless cooling chain and, at an individual level, choosing low-risk food (Jendritzky, 2007; Stöver, 2015).

\section{Further consequences of climate change}

\section{Consequences at individual level}

No overview of this topic would be complete without consideration of the positive effects of climate change at individual level. In the middle latitudes, global warming is likely to lead to an increase in average comfort levels over the year (Stamatakis et al., 2013). For many types of outdoor sports, it means that the outdoor season can start earlier and finish later (Eis et al., 2010; Kappas, 2009). However, more sports opportunities due to milder temperatures in the colder season have to be contrasted with a decline in physical activity due to increased heat waves. Initial studies are to be conducted to investigate whether, climate change will lead to an overall increase or decrease in sporting activities. First prediction studies on cycling use indicate that a heat-related decrease in cycling in the summer may be compensated by a factor of about four to five during the milder rest of the year (Heaney, Carrión, Burkart, Lesk, \& Jack, 2019; Stamatakis et al., 2013). Similar shifts in movement patterns are also predicted for winter sports: Worldwide, climate change is leading to a decrease in snow reliable areas. However, valid studies on the question to what extent a resulting decline in skiing will be at least partially compensated by an expansion of the local offer of alternative mountain sports (mountain biking, hiking, and climbing as 4-season tourism) and further trips to higher snow areas are still lacking (Dawson \& Scott, 2013; Unbehaun, Pröbstl, \& Haider, 2008).

Extended seasons and an increase in the number of sunny days may also entail a behaviour-related increase in exposure to UV radiation. For many athletes, spending more time exercising outdoors means greater cumulative UV exposure, without any need for there to be an increase in radiation strength specifically. A positive effect of this is that it can prevent symptoms of depression (seasonal affective disorder), boost vitamin D levels and reduce the risk of deficiency-related diseases such as osteoporosis (Algesheimer, 2019; Eis et al., 2010; Stöver, 2015).

\section{Consequences at macro level}

This overview only looks at the effects of global climate change that are relevant for individual athletes, thereby only dealing with a small partial aspect of the overall situation. Other factors such as the increasing acidification of the oceans, the melting of land ice and the Arctic ice sheet, loss of biodiversity, increasing water and food shortages and climateinduced human migration are likely to have a greater impact on the future of the human race (Eis et al., 2010; Neuerburg \& Quardokus, 2019; Watts et al., 2019).

\section{Consequences at meso level}

A focus on individual athletes also excludes any consequences for sports organizations. It is not only international 
and national sports bodies (International Olympic Committee, Fédération Internationale de Football Association) that will have to respond to the changes in our climate, but also local clubs and organizations, so that they can protect athletes, spectators, referees, judges and staff appropriately and ensure a plannable continuation of the sport. The first intervention field is the avoidance of climateassociated health risks through structural prevention measures (e.g. implementing heat warning systems and heat guidelines, temperature-dependent scheduling, building sun protection structures, high albedo facade and low albedo floor surface design, natural shade, energyfocused renovation of sports facilities, selection of low allergen plants, and hygiene management at events). The second field of action is the reduction of climate-associated economic risks (e.g. climate-proof planning and execution of major events, designing winter sports programs to compensate for the declining certainty of snow, protecting sports grounds from drought, flooding, hail and storms, and reacting to a fall in spectator numbers in the summer months due to the heat (Algesheimer, 2019; Orr \& Inoue, 2019)). Depending on the context, sports organizations are often faced with the challenge that there are significantly more spectators present at many events than active participants who also fall under the responsibility of the organization (e.g. Olympic Games, major championships, league soccer matches, marathons and people's runs).

At the end of this discussion paper, we return to the article by Abu Omar and Gelius mentioned at the beginning (Abu-Omar \& Gelius, 2020). While the discussion here deals with climate change adaptation, Abu Omar and Gelius emphasised the responsibility of sports clubs and sports organisations for climate change mitigation: Mitigation covers all measures that are likely to abate, delay or reduce climate change. Essentially, climate change mitigation measures are aimed at reducing greenhouse gas emissions (Watts et al., 2019). Mitigation is thus an upstream approach (Eichinger, 2019). In contrast, adaptation refers to making adjustments to accommodate the manifold consequences of climate change (Jendritzky, 2007). Adaptation therefore represents a downstream approach (e.g. "end-of-pipe" approach) (Algesheimer, 2019).

The fact that this article exclusively deals with the topic of adaptation does not mean that sports organizations should not also commit to mitigation strategies as well as adaptation measures. On the contrary, the relationship between climate change and sport is bidirectional (Orr \& Inoue, 2019). Sport not only suffers from the effects of greenhouse gas emissions, but also causes them. Major events such as international and national tournaments, championships and league games cause considerable amounts of sport-related mobility that affect $\mathrm{CO}_{2}$ levels. In this context, the emissions caused by spectators represent by far the greatest potential for greenhouse gas savings (i.e. travel to and from league matches and tournaments; Neuerburg \& Quardokus, 2019; Orr \& Inoue, 2019). Sport also impinges on attractive natural environments such as coastal area, forests and mountains (Neuerburg \& Quardokus, 2019). Sports facilities require energy, e.g. for air conditioning and maintenance. Sports clubs sell products and generate waste (e.g. sports gear, equipment, technology, paper, catering). There is therefore considerable potential to save energy and raw materials within the typical activities related to sports enterprises.

\section{Summary and conclusion}

Climate change is associated with the following increases of health-related risks for athletes in particular: heat stress, UV exposure, exposure to allergens, exposure to air pollutants, spread of vectors and natural reservoirs as well as other risks such as extreme weather events.

From a geological point of view, global climate change is progressing at breakneck speed. From an individual point of view, at the very least, initial indications are beginning to emerge showing the specific impact of climate change on sports. The potential to perceive these events as "a catastrophe in slow motion" might explain why little attention is given and research has been done to date on this global challenge in the fields of sports medicine and sports science. This paper provides an outline of the key fields for research, intervention and prevention within sports medicine and sports science research in the future.

\section{Corresponding address

Prof. Dr. Sven Schneider
Mannheim Institute of Public
Health, Social and Preventive
Medicine, Medical Faculty
Mannheim, Heidelberg
University
Ludolf-Krehl-Straße 7-11,
68167 Mannheim, Germany
sven.schneider@medma.uni-
heidelberg.de

Acknowledgements. We would like to thank Bärbel Holzwarth (M.A.) for her support in researching this article and Lilian Anderson for her help in formally preparing this manuscript (both at the Mannheim Institute of Public Health, Social and Preventive Medicine, Heidelberg University).

Author Contribution. Sven Schneider: Conceptualization, Writing — original draft, Writing review \& editing, Visualization. Hans-Guido Mücke: Conceptualization, Writing —original draft, Writing review \& editing

Funding. Open Access funding enabled and organized by Projekt DEAL.

\section{Declarations}

Conflict of interest. S. Schneider and H.-G. Mücke declare that they have no competing interests.

For this article no studies with human participants or animals were performed by any of the authors. All studies performed were in accordance with the ethical standards indicated in each case.

Open Access. This article is licensed under a Creative Commons Attribution 4.0 International License, which permits use, sharing, adaptation, distribution and reproduction in any medium or format, as long as you give appropriate credit to the original author(s) and the source, provide a link to the Creative Commons licence, and indicate if changes were made. The images or other third party material in this article are included in the article's Creative Commons licence, unless indicated otherwise in a credit line to the material. If material is not included in the article's Creative Commons licence and your intended use is not permitted by statutory regulation or exceeds the permitted use, you will need to obtain permission directly from the copyright holder. To view a copy of this licence, visit http://creativecommons.org/licenses/by/4.0/. 


\section{References}

Abu-Omar, K., \& Gelius, P. (2020). Klima und Sport? Klima und Sport! Ger J Exerc Sport Res, 50(1), 5-9. https://doi.org/10.1007/s12662-019-00630-0.

Algesheimer, G. (2019). Anpassung an die Folgen des Klimawandels bei Sportvereinen: Herausforderungen, Hemmnisse und Potentiale. Universität Kassel.

Baker-Austin, C., Trinanes, J. A., Taylor, N. G. H., Hartnell, R., Siitonen, A., \& Martinez-Urtaza, J. (2013). Emerging Vibrio risk at high latitudes in response to ocean warming. Nat Clim Change, 3(1), 73-77. https://doi.org/10.1038/nclimate1628.

Baldermann, C., \& Lorenz, S. (2019). UV-Strahlung in Deutschland: Einflüsse des Ozonabbaus und des Klimawandels sowie Maßnahmen zum Schutz der Bevölkerung. Bundesgesundheitsblatt, 62(5), 639-645. https://doi.org/10.1007/s00103-01902934-w.

Beggs, P.J., \& Bambrick, H.J. (2005). Is the global rise of asthma an early impact of anthropogenic climate change? Environ Health Perspect, 113(8), 915-919. https://doi.org/10.1289/ehp.7724.

Brasseur, G. P., Jacob, D., \& Schuck-Zöller, S. (2017). Klimawandel in Deutschland: Entwicklung, Folgen, Risiken und Perspektiven. : Springer.

Brotherhood, J. (2008). Heat stress and strain in exercise and sport. J Sci Med Sport, 11(1), 6-19. https://doi.org/10.1016/j.jsams.2007.08.017.

Dawson, J., \& Scott, D. (2013). Managing for climate change in the alpine ski sector. Tourism Management, 35, 244-254.

Deutsche Gesellschaft für Dermatologie. (2016). Kutane Lyme Borreliose. https://www.awmf.org/ uploads/tx_szleitlinien/013-044l_S2k_Kutane Lyme_Borreliose_2016-05.pdf. Accessed 4 Mar 2021.

Deutsche Gesellschaft für Sportmedizin und Prävention. Sport trotz Heuschnupfen - gesund oder schädlich? Deutsche Gesellschaftfür Sportmedizin und Prävention. https://www.dgsp.de/ seite/376555/sport-trotz-heuschnupfen-\%E2 $\% 80 \% 94$-gesund-oder-sch\%C3\%A4dlich.html (Created 2 May 2017). Accessed 5 Nov 2020.

Deutscher Kanu-Verband Achtung: Hitze - Teil 5. Deutscher Kanu-Verband. https://www.kanu. de/Achtung-Hitze-Teil-5-52258.html (Created 10 Nov 2020). Accessed 26 Nov 2020.

Diehl, K., Schneider, S., \& Görig, T. (2019). UV-Exposition - Prävalenz, Bedeutung und Implikationen für die Prävention und Gesundheitsförderung. : Springer. https://doi.org/10.1007/978-3-662-55793-8_ 41-1.

Eichinger, M. (2019). Transformational change in the Anthropocene epoch. Lancet Planet Health, 3(3), e116-e117. https://doi.org/10.1016/S25425196(18)30280-8.

Eis, D., Helm, D., Laußmann, D., \& Stark, K (2010). Klimawandel und Gesundheit - Ein Sachstandsbericht

Faulde, M., Fock, R., Hoffmann, G., \& Pietsch, M. (2002). Tiere als Vektoren und Reservoire von Erregern importierter lebensbedrohender Infektionskrankheiten. Bundesgesundheitsbl, 45(2), 139-150.

Hanna, E., Kjellstrom, T., Bennett, C., \& Dear, K. (2011). Climate change and rising heat: population health implications for working people in Australia. Asia Pac J Public Health, 23(2), 14-26. https://doi.org/10.1177/1010539510391457.

Heaney, A. K., Carrión, D., Burkart, K., Lesk, C., \& Jack, D. (2019). Climate change and physical activity: estimated impacts of ambient temperatures on bikeshare usage in New York city. Environ Health Perspect, 127(3),37002. https://doi.org/10.1289/ EHP4039.

Hemmer, C. J., Emmerich, P., Loebermann, M., Frimmel, S., \& Reisinger, E.C. (2018). Mücken und Zecken als Krankheitsvektoren: der Einfluss der Klimaerwärmung. Dtsch Med Wochenschr, 143(23), 1714-1722. https://doi.org/10.1055/a0653-6333.

Höflich, C. (2014). Klimawandel und Pollen-assoziierte Allergien der Atemwege. UMID, 1, 5-10.

Jendritzky, G. (2007). Folgen des Klimawandels für die Gesundheit(pp. 108-118).

Kaiser, R., Archelos-Garcia, J.J., Jilg, W., Rauer, S., \& Sturzenegger, M. (2017). Frühsommer-Meningoenzephalitis (FSME) [Tick-Borne Encephalitis] Aktuelle Neurol, 44(03), 161-169. https://doi. org/10.1055/s-0043-101424.

Kappas, M. (2009). Klimatologie: Klimaforschung im 21. Jahrhundert - Herausforderung für Natur-und Sozialwissenschaften.: Springer.

Karamfilov, T., \& Elsner, P. (2002). Sport als Risikofaktor und therapeutisches Prinzip in der Dermatologie [Sports as a risk factor and therapeutic principle in dermatology]. Hautarzt, 53(2), 98-103. https://doi.org/10.1007/s001050100204.

Katelaris, C. H., \& Beggs, P.J. (2018). Climate change: allergens and allergic diseases. Intern Med J, 48(2), 129-134. https://doi.org/10.1111/imj. 13699.

Lake, I. R., Jones, N. R., Agnew, M., Goodess, C. M., Giorgi, F., Hamaoui-Laguel, L., Semenov, M. A., Solomon, F., Storkey, J., \& Vautard, R. (2017). Climate change and future pollen allergy in Europe. Environ Health Perspect, 125(3), 385-391. https://doi. org/10.1289/EHP173.

Maloney, S., \& Forbes, C. (2011). What effect will a few degrees of climate change have on human heat balance? Implications for human activity. Int $J$ Biometeorol, 55(2), 147-160. https://doi.org/10. 1007/s00484-010-0320-6.

Mathias, D. (2018). Fit und gesund von 1 bis Hundert: Ernährung und Bewegung - Aktuelles medizinisches Wissen zur Gesundheit. : Springer. https:// doi.org/10.1007/978-3-662-56307-6.

Mücke, H. G., \& Litvinovitch, J. M. (2020). Heatextremes, public health impacts, and adaptation policy in Germany. Int J Environ Res Public Health, 17(21) 7862. https://doi.org/10.3390/ijerph17217862.

Mücke, H. G., \& Matzarakis, A. (2017). Klimawandel und Gesundheit. In H. E. Wichmann \& H. Fromme (Eds.), Handbuch für Umweltmedizin. : Ecomed.

Mücke, H. G., \& Matzarakis, A. (2019). Klimawandel und Gesundheit: Tipps für sommerliche Hitze und Hitzewellen.: Umwelt Bundesamt.

Neuerburg, H., \& Quardokus, B. (2019). Sport in Zeiten der Energiewende - Herausforderungen, Chancen und Perspektiven.: Springer.

Ogden, N. H., \& Lindsay, L. R. (2016). Effects of climate and climate change on vectors and vector-borne diseases: ticks are different. Trends Parasitol, 32(8), 646-656. https://doi.org/10.1016/j.pt. 2016.04.015.

von Orlow, M. (2020). Frühzeitig Grenzen setzen. Spiegel, 36(36), 93.

Orr, M., \& Inoue, Y. (2019). Sport versus climate: Introducing the climate vulnerability of sport organizations framework. Sport Manage Rev, 22(4), 452-463. https://doi.org/10.1016/j.smr. 2018.09 .007$.

Reil, D., Binder, F., Freise, J., Imholt, C., Beyrer, K., Jacob, J., \&Ulrich, R. (2018). Hantaviren in Deutschland: Aktuelle Erkenntnisse zu Erreger, Reservoir, Verbreitung und Prognosemodellen. Berl Münch
Tierärztl Wochenschr. https://doi.org/10.2376/ 0005-9366-18003.

Robert Koch-Institut (2019). Informationen zur Vermeidung von Hantavirus-Infektionen (M. Faber, Ed.). Robert Koch-Institut. https:// www.rki.de/DE/Content/InfAZ/H/Hantavirus/ Merkblatt_PDF.html. Accessed 4Mar 2021.

Robert Koch-Institut (2006). Neuerungen in den aktuellen Empfehlungen der Ständigen Impfkommission (STIKO) am RKI vom Juli 2006. Epid Bull, $32,271-280$.

Schneider, S., Görig, T., Schilling, L., Schuster, A., \& Diehl, K. (2019). Die Nutzung von Sonnenbrillen in Freizeit und Beruf. Ophthalmologe, 116(9), 865-871. https://doi.org/10.1007/s00347-0190850-1.

Schweisfurth, H. (1994). Umweltschadstoff Ozon. Dtsch Med Wochenschr, 119(10), 351-355.

Stamatakis, E., Nnoaham, K., Foster, C., \& Scarborough, P. (2013). The influence of global heating on discretionary physical activity: an important and overlooked consequence of climate change. $J$ Phys Act Health, 10(6), 765-768. https://doi. org/10.1123/jpah.10.6.765.

Stark, K., Niedrig, M., Biederbick, W., Merkert, H., \& Hacker, J. (2009). Die Auswirkungen des Klimawandels. Bundesgesundheitsbl, 52(7), 699-714. https://doi.org/10.1007/s00103-0090874-9.

Stöver, B. (2015). Gesundheit: Effekte des Klimawandels. GWS Discussion Papers(2015/6).

Townsend, M., Mahoney, M., Jones, J., Ball, K., Salmon, J., \& Finch, C.F. (2003). Too hot to trot? Exploring potential links between climate change, physical activity and health. J Sci Med Sport, 6(3), 260-265. https://doi.org/10.1016/ s1440-2440(03)80019-1.

Umweltbundesamt (2016). Ozon bei Sportveranstaltungen. Umweltbundesamt. https://www. umweltbundesamt.de/themen/gesundheit/ umwelteinfluesse-auf-den-menschen/ ozon-bei-sportveranstaltungen\#ozon-beisportveranstaltungen. Accessed 26 Nov 2020.

Umweltbundesamt (2019). GE-I-5: Cyanobakterienbelastung von Badegewässern Fallstudie. Umweltbundesamt. https:// www.umweltbundesamt.de/themen/klimaenergie/klimafolgen-anpassung/folgendes-klimawandels/monitoring-zur-das/dashandlungsfelder-indikatoren/menschlichegesundheit/ge-i-5cyanobakterienbelastung-vonbadegewaessern\#ge-i-5cyanobakterienbelastung-vonbadegewassern-fallstudie. Accessed 26 Nov 2020.

Unbehaun, W., Pröbstl, U., \& Haider, W. (2008). Trends in winter sport tourism: challenges for the future. Tourism Review, 63(1), 36-47.

Watts, N., Amann, M., Arnell, N., Ayeb-Karlsson, S., Belesova, K., Boykoff, M., Byass, P., Cai, W., Campbell-Lendrum, D., \& Capstick, S. (2019). The 2019 report of The Lancet Countdown on health and climate change: ensuring that the health of a child born today is not defined by a changing climate. Lancet, 394(10211), 1836-1878. https:// doi.org/10.1016/S0140-6736(19)32596-6.

Wonisch, M., \& Ledl-Kurkowski, R.P. (2017). Kompendium der Sportmedizin. : Springer.

World Health Organisation (2019). Gesundheitshinweise zur Prävention hitzebedingter Gesundheitsschäden neue und aktualisierte Hinweise für unterschiedliche Zielgruppen. World Health Organisation. https://www.euro.who.int/ 
de/health-topics/Life-stages/healthy-ageing/ publications/2011/public-health-advice-onpreventing-health-effects-of-heat.-new-andupdated-information-for-different-audiences. Accessed 4Mar 2021. 